\title{
ЛІКУВАННЯ ТА ПРОФІЛАКТИКА ТОКСИЧНОГО ГЕПАТИТУ У ХВОРИХ З ЛІМФОПРОЛІФЕРАТИВНИМИ ЗАХВОРЮВАННЯМИ
}

\section{๑о. Є. Самогальська, 3. П. Мандзій \\ Тернопільський національний медичний університет імены І. Я. Горбачевського МОз України}

РЕзЮМЕ. Мета дослідження - вивчити ефективність комбінованого гепатопротектора гепаризин у складі комплексної терапії хворих із гемобластозами.

Матеріал і методи. Під нашим спостереженням перебували 29 хворих із лімфопроліферативними захворюваннями (5 - з гострими лімфобластними лейкеміями, 15 - з хронічними лімфоїдними лейкеміями, 9 - 3 неходжкінськими лімфомами: 6 - з неходжкінськими лімфомами з малих лімфоцитів, а 3 - з неходжкінськими лімфомами з великих гранулярних клітин). Вік хворих становив від 32 до 67 років. Середня тривалість захворювання становила 5-6 років. Усім хворим проводили ультразвукове дослідження органів черевної порожнини (УзД ОЧП) та визначали біохімічні показники функції печінки, а саме аланінамінотрансфаразу, аспартатамінотрансферазу, білірубін, лужну фосфатазу, тимолову та сулемову проби.

Результати. Окрім скарг з приводу основного захворювання (а це загальна слабість, нездужання, тяжкість у нижніх кінцівках, запаморочення), хворих турбували важкість та відчуття розпирання у правому підреберї, нудота. Інколи відмічалась жовтяничність шкіри та слизових оболонок. При УзД ОчП у 22 хворих виявлено збільшення розмірів печінки. У середньому печінка була збільшена за рахунок як правої, так і лівої часток. У 19 хворих спостерігалось підвищення АЛТ та АСТ, у 11 хворих також виявлено підвищення білірубіну за рахунок непрямої фракції. Активність процесу переважно відповідала середньому $(58,7$ \%) та вираженому $(21,3$ \%) ступеням. У процесі отримання як моно-, так і поліхіміотерапії вираженість токсичного впливу на стан функції гепатоцитів посилювалася, на що вказували печінкові проби. Так, показники АЛТ та АСТ підвищувалися, також спостерігалося підвищення рівнів лужної фосфатази, білірубіну за рахунок непрямої фракції. У 5 хворих із гемобластозами спостерігалась жовтяничність шкіри та склер.

Висновки. На основі комплексного лікування із застосуванням препарату гепаризину відмічалась позитивна динаміка клінічного перебігу основного захворювання, яка проявлялася покращенням самопочуття хворого, загального стану, зникненням важкості в правому підребер'ї. Аналіз показників функціональних проб печінки під впливом терапії показав зниження активності запального процесу в гепатоцитах, на що вказували показники АЛТ, АСТ, білірубіну, лужної фосфатази.

У хворих із мінімальною та середньою активністю ці показники поверталась до нормальних величин, а у хворих із вираженою активністю вказані показники зменшувались. Також встановлено позитивний вплив препарату на білковий метаболізм, про що свідчить підвищення загального білка сироватки крові.

КлючОВІ СлОВА: лімфома; хворі; гепаризин; дослідження.

Вступ. За даними сучасних статистичних і епідеміологічних досліджень, останнім часом в Україні значно зросла частота захворюваності на хронічну патологію печінки. Перебіг захворювання супроводжується патологією системи антиоксидантного захисту, на тлі чого розвивається хронічна інтоксикація з метаболічними порушеннями, що негативно впливають на ф ункціональний стан печінки.

Відомо, що, незалежно від етіологічного чинника (хімічні шкідливі речовини, алкоголь, радіація тощо), у патогенетичному плані характерним $\epsilon$ ураження мембран гепатоцитів, і як наслідок, порушення функцій печінки, насамперед білковосинтетичної та детоксикаційної. Окрім того, ушкодження печінки може бути наслідком побічної дії препаратів, які застосовуються при основній патології. А це прийом антибіотиків, імунодепресантів, глюкокортикоїдів та інших лікарських засобів. На сьогодні значну роль у формуванні уражень функції печінки відіграють токсичні фактори. Важливим фактором впливу на функцію печінки $є$ використання сучасних клінічних протоколів лікування хворих з лімфопроліферативними захворюваннями [1]. Підвищення ефективності лікування досягнуто завдяки застосуванню нових препаратів та інтенсифікації режимів хіміотерапії [2, 3]. Проте негативною стороною поліхіміотерапії (ПХТ) $€$ побічна дія протипухлинних лікарських засобів. За даними клінічних досліджень встановлено, що медикаментозне ураження печінки становить близько 10 \% усіх побічних реакцій, пов'язаних із застосуванням цитостатичних препаратів [4-9]. Насправді гепатотоксичність розвивається, мабуть, частіше, ніж свідчить офіційна медична статистика, оскільки печінка є однією з основних ланок біотрансформації цитостатиків $[10,11]$. Однією з основних причин структурно-функціональних порушень гепатоцитів у пацієнтів онкологічного профілює синдром ендотоксикозу, який розвивається в результаті пухлинної інтоксикації, бактерійних та вірусних інфекцій, що приєднуються, а також унаслідок ма- 
Огляди літератури, оригінальні дослідження, погляд на проблему, випадок з практики, короткі повідомлення сивного лізису пухлинної тканини у відповідь на введення протипухлинних препаратів [12, 13]. На сьогоднішній день вивчено й інші механізми пошкодження печінки при прийомі лікарських препаратів, наприклад, механізм імунної гепатотоксичності [13]. Лікарські засоби або їх метаболіти можуть стати гаптеном для білків печінкової паренхіми, викликаючи її імунне пошкодження [14].

При застосуванні протипухлинних препаратів досить часто розвивається їх гепатотоксичний ефект, який проявляється досить широким спектром клініко-морфологічних варіантів патології печінки $[11,15]$. Зокрема, при дослідженні ідарубіцину виявили, що, разом з ураженням печінки за типом гострого гепатиту, може розвиватися печінковий фіброз різного ступеня вираження. Прояв токсичності 6-меркаптопурину характеризується некрозом й ожирінням гепатоцитів, формуванням фіброзу портальних трактів, холестатичним ураженням [16].

Токсичні гепатити можуть розвиватися внаслідок прийому циклофосфаміду (ендоксану), L-аспарагінази, доксорубіцину, а також одного із сучасних протипухлинних препаратів - талідоміду [17]. У гематології застосовують також імунодепресанти, зокрема, циклоспорин, які викликають токсичне ураження печінки. Поєднання різних препаратів може призводити до потенціювання їх гепатотоксичності. Так, дія на печінку 6-меркаптопурину посилюється при паралельному застосуванні доксорубіцину $[8,18]$. Тривале лікування цитостатичними препаратами може спричинити портальну гіпертензію внаслідок формування вираженого фіброзу.

Більшості пацієнтів призначають патогенетичне і симптоматичне лікування для запобігання й лікування токсичного ураження печінки на тлі проведення цитостатичної терапії. Арсенал препаратів цілеспрямованої дії при ураженнях печінки невеликий. До них можна віднести L-карнітин, холоплант, гепадиф, гептрал, гепатокс [2]. Для оцінки ступеня і глибини пошкодження гепатоцитів зазвичай застосовують клініко-біохімічні дослідження цілісності печінкової клітини, її екскреторної активності, холестазу, функціональної здатності печінки, мезенхімальної та імунної реакцій. Враховуючи, що морфологічного дослідження печінки ми не проводили, то аналіз біохімічних показників, з певною часткою ймовірності, дозволяє уточнити рівень і провідний механізм розвитку порушень функції печінки. У клінічній практиці саме зміна лабораторних показників часто $€$ відправним пунктом для проведення диференційної діагностики, визначення форми патології печінки та призначення патогенетичної терапії. На підставі лабораторних показників, а саме рівнів аспартатамінотрансферази (АСТ), аланінамінотрансферази (АЛТ), білірубіну та його фракцій, можна зробити висновок про тяжкість патологічного процесу в печінці, спрогнозувати перебіг захворювання, а також оцінювати ефективність терапії, яка проводиться.

Програма лікування і профілактики гепатотоксичності у пацієнтів з онкологічною патологією має бути комплексною та включати:

- дієтичні заходи;

- медикаментозну терапію;

- встановлення й усунення додаткових чинників, що сприяють розвитку токсичного гепатиту.

Більшості пацієнтів призначають патогенетичне і симптоматичне лікування для запобігання і лікування токсичного ураження печінки на ґрунті проведення цитостатичного лікування. До таких препаратів належить комплексний препарат «Гепаризин», який містить моноамонію гліциризинату еквівалентно гліциризину 40 мг, гліцину 400 мг, L-цистеїну гідрохлориду 20 мг;

Завдяки своєму збалансованому складу препарат здатний впливати одразу на декілька патогенетичних ланок захворювання печінки. Так, фосфоліпіди, які є однією з основних складових гепаризину, забезпечують відповідний захист і відновлюють нормальне функціонування клітин печінки, вбудовуючись у пошкоджені клітинні мембрани гепатоцитів, також позитивно впливають на ліпідний обмін організму. Враховуючи, що гепаризин створений для доповнення біологічно активними речовинами раціону харчування людей, що перебувають під впливом шкідливої дії факторів навколишнього середовища, його збалансована формула сприяє підтриманню нормального функціонального стану гепатобіліарної системи та сприяє регенерації та проліферації гепатоцитів, запобігаючи некрозу клітин печінки. Гепаризин бере участь у здійсненні трансмембранного транспорту в мітохондріях високомолекулярних жирних кислот. Крім того, гепаризин здатний покращувати енергетичний баланс в організмі та збільшувати його витривалість, підвищувати засвоєння протеїнів, вітамінів, вуглеводів, зберігати запас глікогену в печінці, стимулювати кровотворення та виділення кисню еритроцитами, забезпечуючи захисну дію в умовах гіпоксії.

Гепаризин сприяє:

- стабілізації складу жовчі;

- прискоренню процесів регенерації і стабілізації клітинних мембран;

- пригніченню перекисного окиснення ліпідів;

- реакцій на клітини печінки.

Таким чином, гепаризин нормалізує ліпідний та вуглеводний обмін, чинить протинабрякову та мембраностабілізувальну дії, покращує детоксикаційну функцію печінки, виявляє антиоксидантний, 
Огляди літератури, оригінальні дослідження, погляд на проблему, випадок з практики, короткі повідомлення антигіпоксійний та репаративний ефект. Такий широкий спектр фармакологічної дії препарату визначив можливість використання його в комплексному лікуванні хворих із гемобластозами як для лікування токсичних гепатитів, так і для їх профілактики.

Мета - вивчити ефективність комбінованого гепатотропного препарату Гепаризин у складі комплексної терапії хворих з лімфопроліферативними захворюваннями.

Матеріал і методи дослідження. Під нашим спостереженням перебували 29 хворих із лімфопроліферативними захворюваннями (5 - з гострими лімфобластними лейкеміями, 15 - з хронічними лімфоїдними лейкеміями, 9 - з неходжкінськими лімфомами: 6 - з неходжкінськими лімфомами з малих лімфоцитів, 3 хворих - $з$ неходжкінськими лімфомами з великих гранулярних клітин). Вік хворих становив від 32 до 67 років. Середня тривалість захворювання дорівнювала 4,6 року. Всім хворим проводили ультразвукове дослідження органів черевної порожнини (УЗД ОчП) та визначали біохімічні показники функції печінки, а саме рівні аланінамінотрансфарази, аспартатамінотрансферази, білірубіну, лужної фосфатази, тимолову та сулемові проби.

Критерієм включення пацієнтів до дослідження були зміни функціональних печінкових проб, які були пов'язані із початком основного захворювання та його лікуванням. Лікувальний комплекс для усіх пацієнтів включав прийом препаратів базисної терапії, а саме прийом поліхіміотерапії згідно із протоколами стандартного лікування, призначення гормональних препаратів, а саме, преднізолону, з наступним зниженням його дози. Крім базисної терапії пацієнти отримували комплексний гепатотропний препарат гепари-

зин. Препарат призначали по 1 капсулі 2 рази на добу після їди 7 днів до призначення хіміотерапії та 3-4 тижні після лікування в амбулаторних умовах. Через місяць усім хворим проводили контрольне обстеження гепатобіліарної системи.

Результати й обговорення. Окрім скарг 3 приводу основного захворювання (а це загальна слабість, нездужання, тяжкість у нижніх кінцівках, запаморочення), хворих турбували важкість та відчуття розпирання у правому підребер'ї, нудота. Інколи відмічалась жовтяничність шкіри та слизових оболонок. При УЗД ОЧП у 22 хворих спостерігали збільшення розмірів печінки. У середньому печінка була збільшена як за рахунок правої частки, так і лівої. У 19 хворих спостерігали підвищення АЛТ та АCT, у 11 хворих також виявлено підвищення рівня білірубіну за рахунок прямої фракції. Активність процесу переважно відповідала середньому $(58,7 \%)$ та вираженому (21,3 \%) ступеням. У процесі отримання як моно-, так і поліхіміотерапії, токсичний вплив на стан функції гепатоцитів посилювався, на що вказували печінкові проби. Так, показники АЛТ та АСТ підвищувалися, також спостерігалось підвищення рівнів лужної фосфатази, білірубіну за рахунок непрямої фракції. У 5 хворих 3 гемобластозами спостерігали жовтяничність шкіри та склер.

У результаті комплексного лікування із застосуванням гепаризину відмічалась позитивна динаміка клінічного перебігу основного захворювання, яка проявлялася покращенням самопочуття хворого, загального стану, зникненням важкості в правому підреберї. Аналіз показників функціональних проб печінки під впливом терапії показав зниження активності запального процесу в гепатоцитах, на що вказували АЛТ, АСТ, білірубін, лужна фосфатаза (табл. 1).

Таблиця 1. Показники функції гепатоцитів до лікування цитостатиками та після отримання поліхіміотерапії й комбінованого гепатопротектора гепаризин

\begin{tabular}{|l|c|c|c|c|}
\hline \multicolumn{1}{|c|}{ Показники } & Норма & $\begin{array}{c}\text { До лікування } \\
\text { цитостатиками }\end{array}$ & $\begin{array}{c}\text { Після лікування } \\
\text { цитостатиками }\end{array}$ & $\begin{array}{c}\text { Після прийому } \\
\text { гепаризину }\end{array}$ \\
\hline $\begin{array}{l}\text { Загальний білірубін, } \\
\text { мкмоль/л }\end{array}$ & $<18,81$ & $20,01+0,1$ & $29,02+0,1$ & $18,03+0,1$ \\
\hline АлАТ & $<40,00$ & $51,01+0,1$ & $69,01+0,1$ & $35,00+0,1$ \\
\hline АсАТ & $<40,00$ & $44,02+0,1$ & $55,01+0,1$ & $42,01+0,1$ \\
\hline ЛФ & $35-129$ & $130,01+0,1$ & $139,01+0,1$ & $86,01+0,1$ \\
\hline $\begin{array}{l}\text { Загальний білок, } \\
\text { мкмоль/л }\end{array}$ & $65-85$ & $64,02+0,2$ & $59,02+0,1$ & $68,02+0,1$ \\
\hline
\end{tabular}

У хворих із мінімальною та середньою активністю ці показники поверталась до нормальних величин. А у хворих з вираженою активністю показники зменшувались. Також встановлено позитивний вплив препарату на білковий метаболізм, про що свідчить підвищення загального білка сироватки крові.
Висновки. 1. У комплексному лікуванні хворих із лімфопроліферативними захворюваннями обґрунтованим є застосування комбінованого препарату гепаризину, який має широкий спектр фармакологічної дії завдяки детоксикаційним, антигіпоксійним, протизапальним, метаболічним ефектам його компонентів. 
Огляди літератури, оригінальні дослідження, погляд на проблему, випадок з практики, короткі повідомлення

2. Широкий спектр фармакологічної дії препарату визначив можливість використання його в комплексному лікуванні хворих із лімфопроліферативними захворюваннями, як для лікування токсичних гепатитів, так і для їх профілактики.

3. У пацієнтів, які отримували терапію гепаризином на тлі цитостатичної терапії, виявлено статистично достовірну нормалізацію біохімічних показників, які характеризували стан функції печінки. Корекція стану печінки дозволила провести в усіх хворих заплановане цитостатичне лікування. Після закінчення курсу моно-чи поліхіміотерапії в жодного пацієнта не відбулося погіршен-

\section{ЛІТЕРАТУРА}

1. Glutathione-S-transferase enzyme expression in hematopoietic cell lines implies a differential protective role for $\mathrm{TI}$, and $\mathrm{Al}$ isoenzymes in erythroid and for $\mathrm{MI}$ in lymphoid lineages / L. Wang, J. Gloves, M. Hepburn, D. T. Bowen / Haematologica. - 2000. - Vol. 85 (6). - P. 573-579.

2. Жулкевич І. В. Вікова динаміка змін стану мінеральної щільності кісткової тканини у хворих на хронічну лімфоїдну лейкемію / І. В. Жулкевич, Р. Й. Вибирана, К. В. Баранніков // Вісник наукових досліджень. 2013. - № 1. - С. 47-50.

3. Жулкевич І. В. Первинна легенева лімфома 3 бронхоасоційованої лімфоїдної тканини (клінічне спостереження) / І. В. Жулкевич, І. Й. Галайчук // Патологія. - 2019. - Т. 16, № 2 (46). - С. 293-298.

4. Болезни печени и желчевыводящих путей / под ред. В. Т. Ивашкина. - М., 2002. - 432 с.

5. Майер К. П. Гепатит и последствия гепатита : практическое руководство / К. П. Майер. - М., 2004. 720 c.

6. Acute hepatoxicity with intermediate-dose methotrexate inn children with leukemia and non-Hodgkin's lymphoma / P. Exadaktylos, T. Reiss, R. Schobess [et al.] // Klin. Padiatr. - 1994. - Vol. 206 (4). - P. 315-318.

7. Jansen P. L. Intrahepatic cholestasis and biliary cirrhosis associated with extrahepatic Hodgkin's disease / P. L. Jansen, H. Van der Lelie // Neth. J. Med. - 1994. Vol. 44 (3). - P. 99-102.

8. Levis J. H. Methotrexat-induced chronic liver injury: guidelines for detection and prevention / J. H. Levis, E. Schiff // Am. J. Gastroenterol. - 1998. - Vol. 83 (12). P. $1337-1345$.

9. Зміни структурно-функціонального стану кісткової тканини під впливом хіміотерапевтичних середни- ня функції печінки, про що свідчать показники печінкових проб.

4. У пацієнтів з онкогематологічними захворюваннями для запобігання гепатотоксичності на тлі проведення хіміотерапії і для зменшення вираження вже розвинутих проявів гепатопатії необхідне долучення до протоколу лікування препаратів патогенетичної терапії синдрому цитолізу.

5. Захисна дія комбінованого препарату гепаризину дозволить зменшити кількість вимушених змін у протоколах поліхіміотерапії, пов'язаних з ураженням печінки, поліпшити переносимість моно- та поліхіміотерапії, підвищити якість життя пацієнтів у період лікування і реабілітації.

ків у хворих на хронічну лімфоїдну лейкемію / І. В. Жулкевич, Р. Й. Вибирана // Шпитальна хірургія. - 2013. № 3. - С. 83-92.

10. Городецкий В. М. Осложнения противоопухолевой терапии / В. М. Городецкий // Гематология и трансфузиология. - 1998. - № 1. - С. 11-15.

11. Клиническая онкогематология / под ред. М. А. Волковой. - М. : Медицина, 2001. - 572 с.

12. Frezza M. The use of S-adenosyl-L-methiorline in the treatment of cholestatic disorders. A meta-analysis of clinical trials / M. Frezza, M. Terpin // Drug Invest. - 1992. Vol. 4 (Suppl. 4). - P. 101-108.

13. Direct cell-to-cell contact between Kupfer cells and hepatocytes augments endotoxin-induced hepatic injury / K. H. Hoebe, R. F. Witkamp, J. Fink-Gremmels [et al.] // Am. J. Physiol. Gastrointest. Liver Physiol. - 2001. Vol. 280 (4). - P. G720-728.

14. Santini D. S-adenosylmethionine (AdoMet) supplementation for treatment of chemotherapy-induced liver injury / D. Santini, B. Vincenzi, C. Massacesi [et al.] // Anticancer Res. - 2003. - Vol. 23 (6D). - P. 5173-5179.

15. Glutathione metabolism and phisiological functions / J. Vina ed. - Boston, 1990. - 378 p.

16. Кан В. К. Холестаз: новое в патогенезе, диагностике и лечении / В. К. Кан // Российский журнал гастроэнтерологии, гепатологии. - 1997. - № 3. - С. 25-29.

17. Fowler R. Thalidomide-associated hepatitis: a case report / R. Fowler, K. Imrie // Am. J. Hematol. - 2001. Vol. 66 (4). - P. 300-302.

18. Laidlaw S. T. Fatal hepatotoxicity associated with 6-mercaptopurine therapy / S. T. Laidlaw, J. T. Reilly, S. K. Suarna // Postgrad. Med. J. - 1995. - Vol. 71 (840). P. 639.

\section{REFERENCES}

1. Wang, L., Gloves, J., Hepburn, M., \& Bowen, D.T. (2000). Glutathione-S-transferase enzyme expression in hematopoietic cell lines implies a differential protective role for $\mathrm{TI}$, and $\mathrm{Al}$ isoenzymes in erythroid and for Ml in lymphoid lineages. Haematologica, 85 (6), 573-579.

2. Zhulkevych, I.V., Vybyrana, R.Y., \& Barannikov, K.V. (2013). Vikova dynamika zmin stanu mineralnoi shchilnosti kistkovoi tkanyny u khvorykh na khronichnu limfoidnu leikemiiu [Age dynamics of bone mineral density in patients with chronic lymphoid leukemia]. Visnyk naukovykh 
Огляди літератури, оригінальні дослідження, погляд на проблему, випадок з практики, короткі повідомлення doslidzhen - Bulletin of Scientific Research, 1, 47-50 [in Ukrainian].

3. Zhulkevych, I.V., \& Halaichuk, I.Y. (2019). Pervynna leheneva limfoma z bronkhoasotsiiovanoi limfoidnoi tkanyny (klinichne sposterezhennia) [Рrimary pulmonary lymphoma from bronchus-associated lymphoid tissue (clinical observation)]. Patolohiia - Patolhogy, 16, 2 (46), 293-298 [in Ukrainian].

4. Ivashkina, V.T. (Ed.) (2002). Bolezni pecheni i zhelchevyvodyashchikh putey [Diseases of the liver and biliary tract]. Moscow [in Russian].

5. Mayyer, K.P. (2004). Gepatit i posledstviya gepatita: prakticheskoye rukovodstvo [Hepatitis and the consequences of hepatitis: a practical guide]. Moscow [in Russian].

6. Exadaktylos, P., Reiss, T., Schobess, R., Hommann, M., Höhne, S., \& Beck, A. (1994). Acute hepatoxicity with intermediate-dose methotrexate inn children with leukemia and non-Hodgkin's lymphoma. Klin. Padiatr., 206 (4), 315-318.

7. Jansen, P.L., \& Van der Lelie, H. (1994). Intrahepatic cholestasis and biliary cirrhosis associated with extrahepatic Hodgkin's disease. Neth. J. Med., 44 (3), 99-102.

8. Levis, J.H., \& Schiff, E. (1998). Methotrexat-induced chronic liver injury: guidelines for detection and prevention. Am. J. Gastroenterol., 83 (12), 1337-1345.

9. Zhulkevych, I.V., \& Vybyrana, R.Y. (2013). Zminy strukturno-funktsionalnoho stanu kistkovoi tkanyny pid vplyvom khimioterapevtychnykh serednykiv u khvorykh na khronichnu limfoidnu leikemiiu [Changes in the structural and functional state of bone tissue under the influence of chemotherapeutic agents in patients with chronic lymphoid leukemia]. Shpytalna khirurhiia - Hospital Surgery, 3, 83-92 [in Ukrainian].

10. Gorodetskiy, V.M. (1998). Oslozhneniya protivoopukholevoy terapii [Complications of antineoplastic therapy]. Gematologiya i transfuziologiya - Hematology and Transfusiology, 1, 11-15 [in Russian].

11. Volkova, M.A. (Ed.) (2001). Klinicheskaya onkogematologiya [Clinical hematology oncology]. Moscow: Meditsina [in Russian].

12. Frezza, M., \& Terpin, M. (1992). The use of S-adenosyl-L-methiorline in the treatment of cholestatic disorders. A meta-analysis of clinical trials. Drug Invest., 4 (4), 101-108.

13. Hoebe, K.H., Witkamp, R.F., Fink-Gremmels, J., Van Miert, A.S., \& Monshouwer, M. (2001). Direct cell-to-cell contact between Kupfer cells and hepatocytes augments endotoxin-induced hepatic injury. Am. J. Physiol. Gastrointest. Liver Physiol., 280 (4), G720-728.

14. Santini, D., Vincenzi, B., Massacesi, C., Picardi, A., Vespasiani Gentilucci, U., Esposito, V., ..., \& Tonini, G. (2003). S-adenosylmethionine (AdoMet) supplementation for treatment of chemotherapy-induced liver injury. Anticancer Res., 23 (6D), 5173-5179.

15. Vina, J. (Ed.) (1990). Glutathione metabolism and phisiological functions. Boston.

16. Kan, V.K. (1997). Kholestaz: novoye v patogeneze, diagnostike i lechenii [Cholestasis: new in pathogenesis, diagnosis and treatment]. Rossiyskiy zhurnal gastroenterologii, gepatologii - Russian Journal of Gastroenterology, Hepatology, 3, 25-29 [in Russian].

17. Fowler, R., \& Imrie, K. (2001). Thalidomide-associated hepatitis: a case report. Am. J. Hematol., 66 (4), 300-302.

18. Laidlaw, S.T., Reilly, J.T., \& Suarna, S.K. (1995). Fatal hepatotoxicity associated with 6-mercaptopurine therapy. Postgrad. Med. J., 71 (840), 639.

\section{ЛЕЧЕНИЕ И ПРОФИЛАКТИКА ТОКСИЧЕСКОГО ГЕПАТИТА У БОЛЬНЫХ ЛИМФОПРОЛИФЕРАТИВНЫМИ ЗАБОЛЕВАНИЯМИ}

\section{๑Е. Е. Самогальская, 3. П. Мандзий}

\section{Тернопольский национальный медицинский университет имени И. Я. Горбачевского МОз Украины}

РЕЗЮМЕ. Цель исследования - изучить эффективность применения комбинированного гепатопротектора гепаризин в рамках комплексной терапии у больных лимфопролиферативными заболеваниями.

Материал и методы. Под нашим наблюдением находилось 29 больных лимфопролиферативными заболеваниями (5 - с острыми лимфобластными лейкемиями, 15- с хронической лимфоидной лейкемией, 9-с неходжкинскими лимфомами: 6 - неходжкинскими лимфомами из малых лимфоцитов и 3 пациента с неходжкинскими лимфомами из больших гранулярных клеток). Возраст больных колебался от 32 до 67 лет. Средняя продолжительность заболевания составила 5-6 лет. Всем больным проводили УзИ органов брюшной полости и определение биохимических показателей функции печени, а именно аланинаминотрансферазы и аспартатаминотрансферазы, билирубина, щелочной фосфатазы, тимоловой и сулемовой проб.

Результаты. Помимо жалоб по поводу основного заболевания (это общая слабость, недомогание, тяжесть в нижних конечностях, головокружение), больных беспокоили тяжесть в правом подреберье, тошнота. Иногда отмечалась желтизна кожи и слизистых оболочек. При УЗ обследовании печени у 22 больных отмечалось увеличение ее размеров. В среднем печень была увеличена как за счет правой, так и левой долей. У 19 пациентов отмечалось повышение АЛТ и АСТ, у 11 больных также увеличение билирубина за счет непрямой фракции. Активность заболевания главным образом отвечала средней $(58,7$ \%) и $(21,3$ \%) тяжелой степени заболевания. В процессе как моно-, так и полихимиотерапии выраженность влияния токсических эффектов на функцию гепатоцитов увеличивалась. Ппоказатели АЛТ и АСТ увеличивались, отмечалось повышение щелочной фосфатазы, билирубина, в основном непрямой фракции. У 5 больных с гемобластозами отмечалась желтизна склер и кожи.

Выводы. В результате комплексного лечения с использованием препарата гепаризин отмечалась положительная динамика клинического течения основного заболевания. При этом отмечалось общее состояние пациен- 
Огляди літератури, оригінальні дослідження, погляд на проблему, випадок з практики, короткі повідомлення та, исчезновение ощущения тяжести в правом подреберье. Анализ показателей функциональных проб печени под влиянием терапии показал снижение активности воспалительного процесса в гепатоцитах. Улучшились показатели АЛТ, АСТ, билирубина, щелочной фосфатазы.

У больных с минимальной и средней активностью заболевания эти показатели возвращались К нормальным значениям, а у больных с выраженной активностью процесса эти показатели значительно улучшались. Отмечалось положительное влияние препарата на белковый обмен, о чем свидетельствует нормализация общего белка сыворотки крови.

КЛЮЧЕВЫЕ СЛОВА: лимфома; больные; гепаризин; исследование.

\section{TREATMENT AND PREVENTION OF TOXIC HEPATITIS IN PATIENTS WITH LYMPHOPROLIFERATIVE DISEASES}

\section{@O. E. Samogalska, Z. P. Mandziy}

\section{Horbachevsky Ternopil National Medical University}

SUMMARY. The aim - to study the effectiveness of the combined hepatoprotector geparizine as part of complex therapy in patients with hemoblastomas.

Material and Methods. We observed 33 patients with hemoblastomas ( 3 acute lymphoblastic leukemias, 5 with acute myeloid leukemia, 13 with chronic lymphoid leukemia, and 11 patients with chronic myeloid leukemia) aged 32 67 years. The average duration of the disease was 4-6 years. All patients underwent ultrasound examination of the abdominal cavity (ultrasound examination) and biochemical parameters of the liver function, namely, alanine aminotransferase, aspartate aminotransferase, bilirubin, alkaline phosphatase, timolol and sulam samples.

Results. In addition to complaints of the underlying disease (which is general weakness, anomalies, heaviness in the lower extremities, dizziness), the patients were concerned about the severity and sensation of dislocation in the right hypochondrium, nausea. Occasionally, jaundice of the skin and mucous membranes was observed. With ultrasound examination in 19 patients, an increase in liver size was observed. The liver was enlarged at the expense of both particles. In 11 patients, there was an increase in ALT and AST, and in 11 patients, increased bilirubin was observed due to an indirect fraction. The activity of the process mostly corresponded to an average of $58.7 \%$, and a pronounced $21.3 \%$ degree. In the process of obtaining both mono and polychemotherapy, the activity of the severity of toxic effects on the state of hepatocyte function increased, as indicated by an increase in liver samples. Thus, ALT and AST elevations were observed, as well as an increase in alkaline phosphatase, bilirubin due to an indirect fraction. Yellowing of the skin and sclera was observed in 5 patients with hemoblastosis.

Conclusions. On the basis of complex treatment with the use of the drug heparizin there was a positive dynamics of the clinical course of the underlying disease, which manifested itself in improved well-being of the patient, general condition, disappearance of heaviness in the right hypochondrium. Analysis of liver function tests under the influence of therapy showed a decrease in the activity of the inflammatory process in hepatocytes what indicated ALT, AST, bilirubin, alkaline phosphatase.

In patients with minimal and moderate activity, the activity of these indicators returned to normal. And in patients with severe activity, these indicators decreased. The positive effect of the drug on protein metabolism was also established, as evidenced by the increase in total serum protein.

KEY WORDS: lymphoma; patients; heparizin; research. 